\title{
Evaluation of the Types of Starch for Preparation of LDPE/Starch Blends
}

\author{
Glória Maria Vinhas*, Suzana Moreira de Lima, Lívia Almeida Santos, Maria Alice \\ Gomes de Andrade Lima and Yêda Medeiros Bastos de Almeida \\ Departamento de Engenharia Química; Universidade Federal de Pernambuco; Rua Prof.Artur de Sá, s/n; Cidade \\ Universitária; gmvinhas@yahoo.com.br; 50740-521;Recife - PE - Brasil
}

\begin{abstract}
This study evaluated in relation the growth, and the amylolytic activity of mixed and isolated cultures of Phanerochaete chrysosporium and Talaromyces wortmanni on different types of starch. The thermal and mechanical properties in polyethylene/starch blends (proportion: $80 / 20(\mathrm{w} / \mathrm{w})$ before and after inoculation of the mixed cultures were evaluated. The regular starch Amidex 3 and the modified starch Fox5901 stood out in relation to the cellular growth and production of the amylase enzyme. In spite of the short time that the blends were exposed to the fungi, the microorganisms promoted physical and chemical changes in the structure of the blend, modifying its thermal and mechanical properties. The alteration of the degree of crystallinity and mechanical properties of the blends could be indications of the modification caused by the biodegradation process.
\end{abstract}

Key words: Amylolytic enzymes; polyethylene; starch; blends; Talaromyces wortmanii; Phanerochaete crysosporium

\section{INTRODUCTION}

The scientific knowledge and the technological advances in the field of polymers have enabled the development of several applications of these materials. However, the accelerated consumption of polymers, mainly in the applications of disposables, like for example packaging, has roused strong concerns due to the generation of residues from the polymeric materials.

Biodegradable polymers are recently developed materials in the field of polymers. Their main characteristic is that they are biodegradable through the action of the microorganism in appropriate environmental conditions. When in contact with the biodegradable polymer, the microorganisms produce enzymes that break down the material in progressively smaller segments; that is to say, they reduce its average molecular mass, favoring its degradation in the environment (Dupret, et al., 1999; Bonhomme et al., 2003; Nakamura et al., 2005). Studies are being conducted to prepare new thermoplastic materials, composed of blends of synthetic polymer with natural polymer, that are degraded more easily when discarded in the environment (Chandra and Rustgi, 1996; Cha and Pitt, 1989; Pedroso and Rosa, 2004).

There is great interest in incorporating biodegradable materials such as starch into conventional plastics such as polyethylene (Kim, 2003; Rodriguez-Gonzalez et al., 2003; Matzinos

\footnotetext{
${ }^{*}$ Author for correspondence
} 
et al., 2002; Baldev et al., 2001). Starch is a polysaccharide that is gaining great importance in the field of new materials and the environment. Besides improving the biodegradable capacity of the microorganisms, the type of starch used in the making of polymeric blends can interfere directly in the properties of the polymer (Thakore et al., 2001).

The polymeric system composed of a mixture of the conventional plastic with the biodegradable polymer is believed to produce a type of plastic material with different mechanical properties, presenting resistance to heat, light and humidity. When this material is discarded into the environment, it can be degraded by microorganism whose natural habitat is the same soil (Ratto et al., 1999; Lima, 2005; Nakamura et al., 2005).

In this paper we present a study of the different types of starch in relation to the growth and the amylolytic activity of mixed and isolated cultures of the fungi Phanerochaete chrysosporium and Talaromyces wortmannii. The thermal and mechanical properties of the polymeric blends of polyethylene/amphoteric starch through the action of mixed cultures of these fungi were also evaluated. The aim was to compare the biodegradation process performance for both systems.

\section{MATERIAL AND METHODS}

\section{Polymer}

A polyethylene of low density (LDPE) was the polymer used; it was supplied by BRASKEM. The different types of starch were supplied by Corn Products of Brazil (Table 1). Few works used modified starches to obtain films from polyethylene blends with starch (Shah, Bandopadhyay and Bellare, 1995; Zuchowska et al. 1998; Thakore et al. 2001; RodríguezGonzalez et al. 2003). The amphoteric starch with the $\mathrm{N}^{+}$and $\mathrm{P}^{-}$ions and the starch Fox 5814 with cation $\mathrm{N}^{+}$were chosen.

Table 1- Different types, sources and characteristics of the starch.

\begin{tabular}{|c|c|c|c|}
\hline Product & Type of Starch & Source of Starch & Characteristics \\
\hline Amidex $® 3$ & Regular & Hybrid corn & $\begin{array}{l}\text { High Mw and Viscosity, } \\
\text { retrogrades }\end{array}$ \\
\hline Amidex ${ }^{\circledR} 4$ & Regular & Corn waxy & $\begin{array}{l}\text { High Mw and Viscosity, } \\
\text { no-retrogrades }\end{array}$ \\
\hline Amisol® & Dextrin & Hybrid corn & Low Mw and Viscosity \\
\hline Fox $® 5814$ & Cationic & Hybrid corn & High substitution degree \\
\hline Fox ${ }^{\circledR} 5901$ & Amphoteric & Hybrid corn & Low substitution degree \\
\hline
\end{tabular}

Obs: Hybrid corn $=27 \%$ amylose and $73 \%$ amylopectin

Waxy Corn $=100 \%$ amylopectin

$\mathrm{Mw}=$ Molecular weight

\section{Microorganism}

A strain of Phanerochaete chrysosporium (Ph) from the culture collection at the Federal University of Rio de Janeiro- Brazil and a wild strain of Talaromyces wortmannii (BM-10) isolated from the soil of the Muribeca Landfill (Jaboatão dos Guararapes - PE - Brazil) were used.

\section{Maintenance of the fungus cultures}

The strains of fungi were maintained in a Sabouraud-agar medium containing $(\mathrm{g} / \mathrm{L})$ : peptone (10), glucose (40), $\mathrm{NaCl}$ (7.5), meat extract (3.5), agar (12) and distilled water (1L). The $\mathrm{pH}$ was adjusted to 4.5 and the sterilization was accomplished at $110^{\circ} \mathrm{C}$ for 20 minutes. The strains were stored at $5^{\circ} \mathrm{C}$.

\section{Biomass}

The mixed and isolated fungus cultures in different types of starches were cultivated in Erlenmeyer flasks containing a Sabouraud-agar medium of $25 / 75 \% \mathrm{w} / \mathrm{w}$ starch/glucose and $100 \%$ starch. The initial spore concentration was $10^{6}$ spores $/ \mathrm{mL}$. The growth was obtained through agitation at $200 \mathrm{rpm}$ 
at room temperature during 14 days, then the content of each flask was filtered through J.PROLAB No 0,007 filter paper. Harvested biomass was washed twice with $200 \mathrm{~mL}$ of distilled water and dried at $105 \pm 1{ }^{\circ} \mathrm{C}$. This experiment was carried out in triplicate.

\section{Amylolytic activity}

The test for detection of the amylases formation was accomplished by cultivating the fungi in petri dishes containing a Sabouraud-agar medium of 25 and $100 \%$ starch, respectively. The mixtures were prepared for the substitution of the glucose in weight for the respective ones percentile of starch in the form of fine powder. Each dish was inoculated with a platinum needle and incubated at $28^{\circ} \mathrm{C}$ for 7 days. Amylolytic activity was validated, in triplicate for each fungus, through the addition of metallic iodine producing a blue coloration in the presence of starch. For quantitative evaluation of the amylase enzyme the respective diameters of de cycle and the colony were measured (Lima, 1999; Rodrigues and Garcia, 1993). The areas of the degradation circle were calculated applying the formulas:

$$
\mathrm{S}=\left(\mathrm{d}_{\mathrm{c}} / 2\right)^{2}-\left(\mathrm{d}_{\mathrm{co}} / 2\right)^{2}
$$

Where: $S=$ area of the circle or total activity; $d_{c}=$ Diameter of the circle; $d_{c o}=$ Diameter of the colony.

\section{Processing of the film}

In this study LDPE/starch blends were utilized, in the proportion of $80 / 20(\mathrm{w} / \mathrm{w})$, mixed by fusion in the mixture chamber of a HAAKE 90 rheometer under the following conditions: control temperature: $140^{\circ} \mathrm{C}$; maximum torque: $50 \mathrm{Nm}$; rotor velocity: $50 \mathrm{rpm}$; total time of mixing: 10 min. The LDPE/starch blend resins, which were processed in the rheometer, were triturated and compressed in a hydraulic press for the obtaining of films perfectly homogeneous with thickness of the $17.5^{ \pm} 2.5 \mathrm{~mm}$.

\section{Biodegradation activity test in polymeric blends}

The mixed culture was tested with regard to their ability to degrade polymeric films according to the methodology developed by Lee et al. (1991) (Rosa et al., 2001; Lima, 2005). The modification in the polymeric structure was investigated through the thermal properties of previously degradation the films by Differential Scanning Calorimetry (DSC) and mechanical tests.

\section{Differential Scanning Calorimetry (DSC)}

A Thermal properties study was conducted using a Shimadzu thermal analyzer with a DSC TA-50 module in a nitrogen atmosphere. Samples of 5-10 $\mathrm{mg}$ were sealed in aluminium dishes and subjected to heating-cooling cycles. The sample was heated up at a rate of $10^{\circ} \mathrm{C} / \mathrm{min}$.

\section{Mechanical test}

The mechanical tests were conducted in an EMIC DL $500 \mathrm{MF}$ universal testing machine, observing the ISO 37 standard. On the basis of this analysis, the tensile strength and elongation at break percentage were determined.

All results obtained were appraised through statistical analyses, using the program STATISTIC 22 (1998).

\section{RESULTS AND DISCUSSION}

The samples were analyzed in triplicate, and Student's $t$ test was applied to evaluate the statistically significant differences in their properties (Miller and Miller, 1984).

The Phanerochaete chrysosporium (Ph) was chosen since this fungus has been used in works concerning with the biodegradation of polymeric blends (Aitken and Irvine, 1989; Eriksson et al., 1990; Orhan and Buyukgungor, 2000). The strain Talaromyces wortmannii (BM-10) was chosen because it was not a pathogenic fungus besides it is the second species more common of the existent in soil, having been isolated in several continents (Domsch and Gams, 1980). Whereas the other isolated strains from the Landfill soil were.

\section{Selection of the starch}

Fig. 1 presents the biomass of the isolated and mixed cultures of chrysosporium and wortmannii, in the different types of starch, in a culture medium containg 25/75\% w/w starch/glucose. chrysosporium presented favorable growth in the medium containg starch of the amidex 3 and Fox5901 types (Fig. a). Apparently the structural characteristics of those starches favored the growth of fungus. Amidex 3 is a regular starch extracted from hybrid corn, composed of $25 \%$ amylose and $75 \%$ amylopectin. In this type of starch, there is an amorphous and crystalline area, due to the presence of amylopectin and amylose, respectively. The enzymatic attack possibly 
favored the liberation of the glucose initially in the disordered area in the structure of the starch, which was consumed as a source of complementary carbon.

The Fox5901 starch is a modified starch that contains in its structure a cation $\left(\mathrm{N}^{+}\right)$and an anion $\left(\mathrm{P}^{-}\right)$. chrysosporium presented favorable growth in this type of starch (Fig. 1a). It was believed that besides carbon source, the other nutrients such as phosphorus and nitrogen mighty have contributed to the consumption of this type of starch.
The behavior of wortmannii in the medium containing $25 \%$ starch demonstrated that the starches Amidex 3 and Fox5901 were responsible for the most favorable biomass production when compared with the other types of starch (Fig. 1b). The mixed culture presented better growth in the culture medium containing $25 \%$ regular starches (Amidex 3 and Amidex 4). However the biomass production in the modified starches, the cationic starch and the amphoteric starch, resulted in the same statistic results (Fig. 1c).
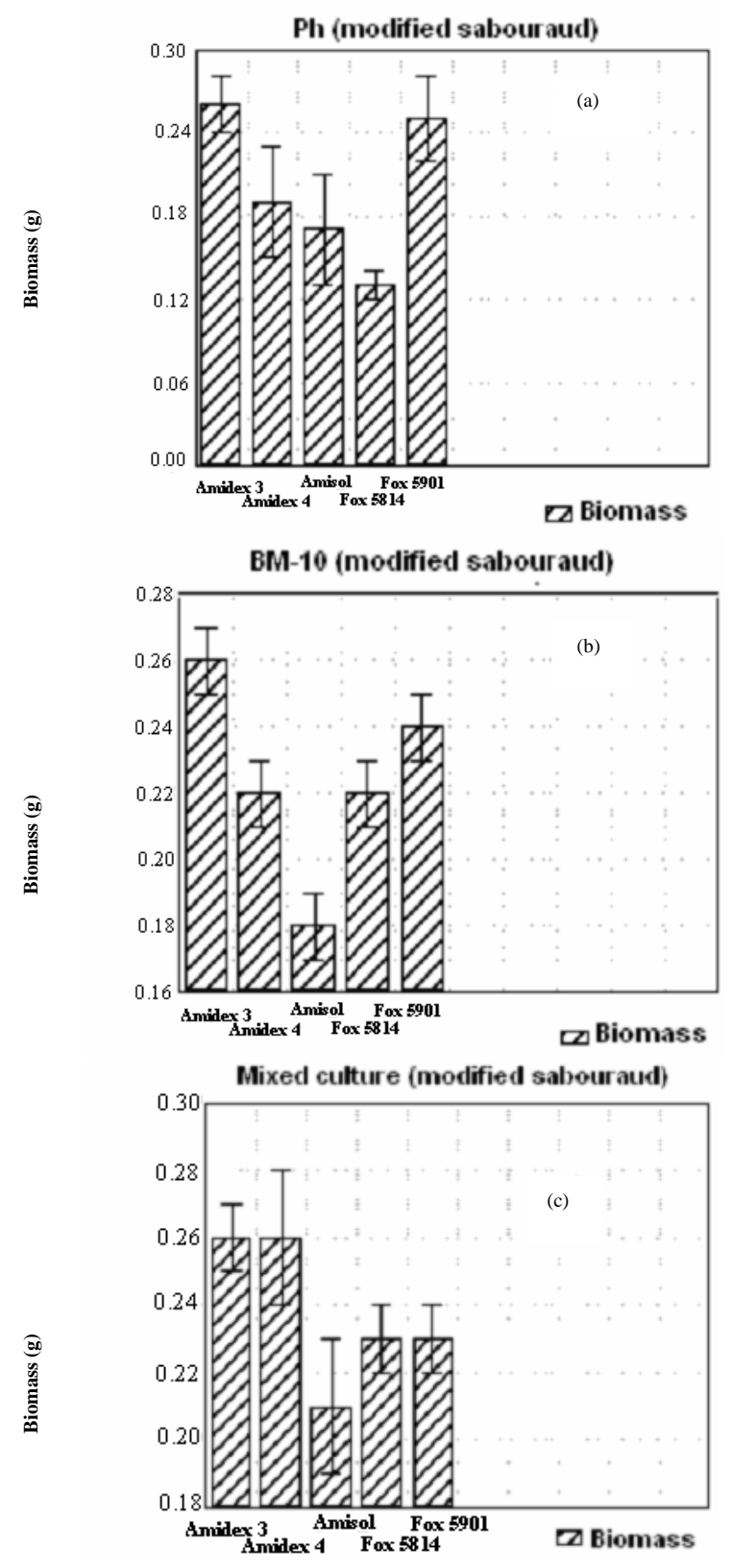

Figure 1- Biomass of the isolated cultures of (a) Phanerochaete chrysosporium, (b) Talaromyces wortmannii and (c) mixed culture, respectively, in the different types of starch/glucose. 
Fig. 2 represents the biomass of the isolated and mixed cultures of chrysosporium and wortmannii, in a medium of $100 \%$ starch. Results showed that the isolated and mixed cultures of the fungi produced more biomass in the medium of $100 \%$ starch than in the medium of $75 \%$ glucose and $25 \%$ starch (Fig. 1). chrysosporium presented the same biomass production $(0.59 \mathrm{~g})$ in cultivation media Amidex 3 and Fox5901 (Fig. 2a). wortmannii produced the largest quantity of biomass $(0.28 \mathrm{~g})$ in the medium containing the Amisol starch (Fig. 2b). This favorable cellular growth could have occurred because it was a starch of low molecular weight. However, the growth of the mixed culture (Fig. 2c) was very satisfactory in the studied types of starch, distinctly indicating as the best source of carbon the regular starches (Amidex 3 and Amidex 4).
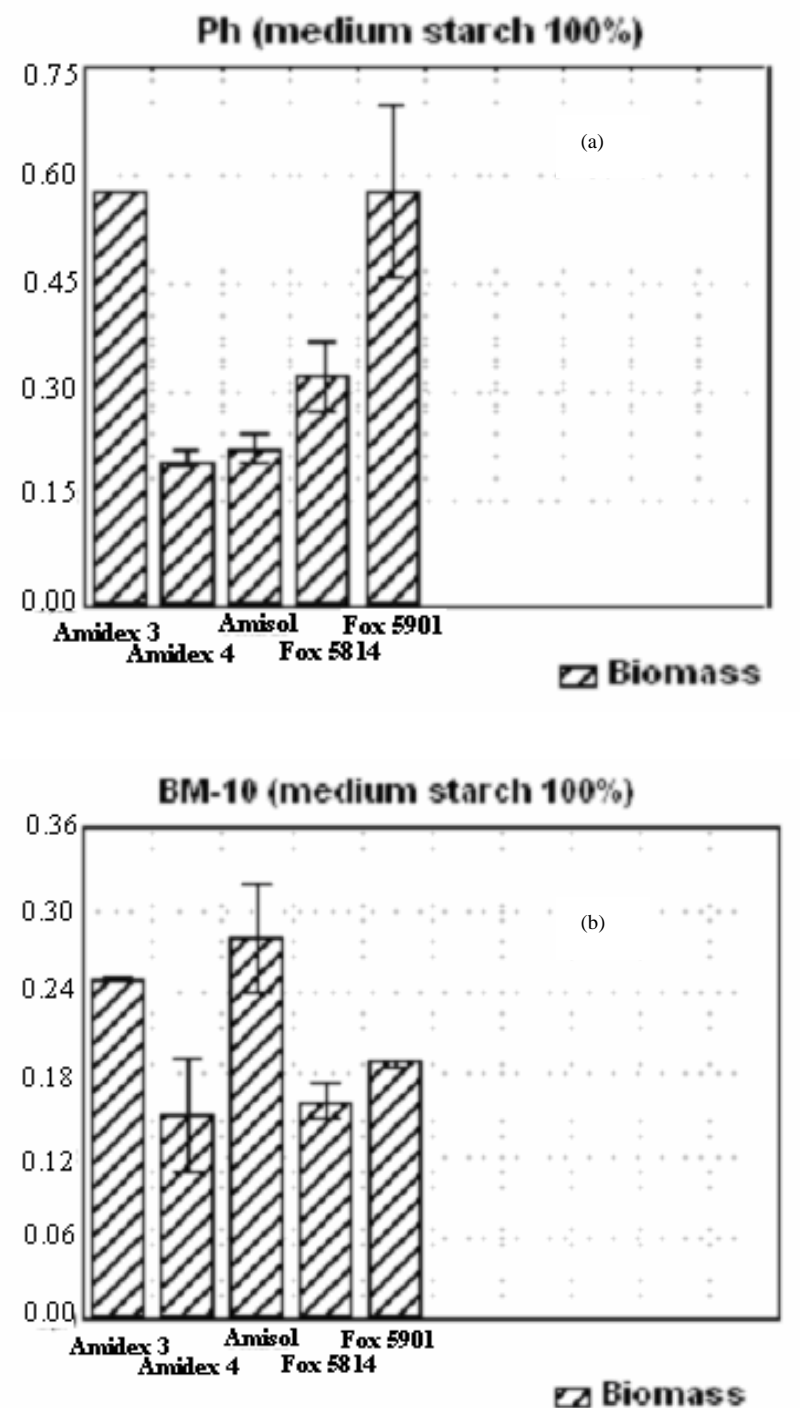


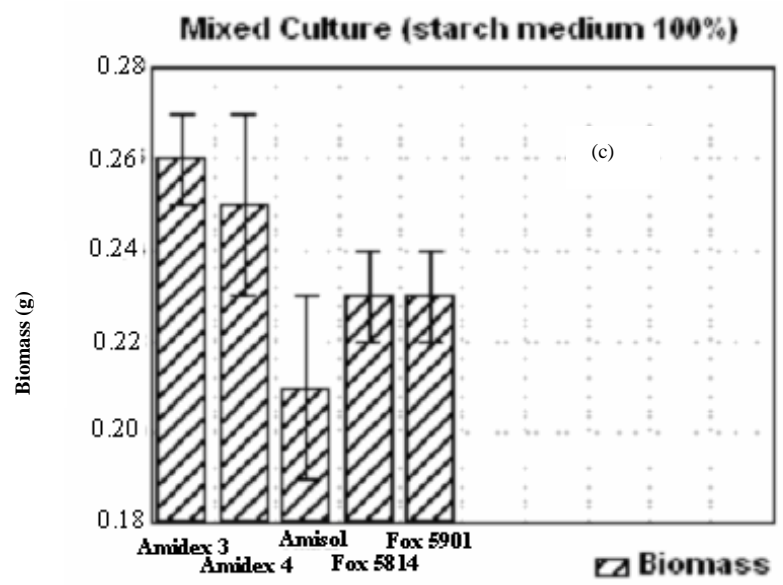

Figure 2- Biomass of the cultures of (a) Phanerochaete chrysosporium, (b) Talaromyces wortmannii and (c) mixed culture, respectively, in the different types of starch.

One of the important factors in justifying the cellular growth of the fungi in different media of starch was the evaluation of the production of the amylase enzyme. Amylases are enzymes that hydrolyze starch molecules resulting in a variety of products of low molecular weight, composed of units of glucose, which are consumed as a carbon source by the fungi (Dey et. al. 1991; RoldánCarrillo et al. 2003). Microorganisms produce two categories of amylase: endoamylases and exoamilases. Endoamylases catalyze hydrolysis in the inner of the starch molecule randomly. This causes the formation of linear and branched oligosaccharides of various chain lengths. Exoamylases hydrolyze from the nonreducting end, successively resulting in short end products (Gupta, et al., 2003). Fig. 4 shows the amylase production by the wortmannii in different types of starch over a period of 7 days. Fig. 3a represents the amylase production in the medium containing $25 \%$ starch and $75 \%$ glucose. The production was more pronounced in the medium containing the regular starch Amidex 3 (3.3 $\mathrm{cm}^{2}$ ). According to Fig. 3b, the enzyme production in the medium containing $100 \%$ starch also induced a higher production of this enzyme brought about by the fungus. The regular starch Amidex $3\left(3.3 \mathrm{~cm}^{2}\right)$ and the modified starch Fox5901(3.0 $\left.\mathrm{cm}^{2}\right)$ were distinctively indicated as favorable.

In all the types and compositions of starch, chrysosporium presented a fast cellular growth over the whole area of the dish, complicating the detection of the amylase production. The results obtained on the cellular growth and amylase production by chrysosporium and wortmannii in the medium containing 25 and $100 \%$ starch were satisfactory. Therefore, they indicated that the types of starch studied were able to compose biodegradable polymeric blends.

\section{Evaluation of the biodegradation of the blends}

For the evaluation of the biodegradation of the polyethylene/starch blend by the mixed culture of the fungi, the Fox5901 starch was used. To evaluate the compatibility of the polyethylene and starch mixture, thermal analyses of the starch, polyethylene and polyethylene/starch were carried out. Fig. 4 presents the thermal analysis of the LDPE, starch and polyethylene/starch blends.

The LDPE (Fig. 4a) showed a glass transition temperature of $83^{\circ} \mathrm{C}$ and a melting temperature of $115^{\circ} \mathrm{C}$, whereas the amphoteric starch Fox5901 presented a melting temperature of $64^{\circ} \mathrm{C}$ (Fig. $4 \mathrm{~b}$ ). The mixture of LDPE with starch (Fig. 4c), in the proportion of $80 / 20 \mathrm{w} / \mathrm{w}$, resulted in a compatible blend, with only one melting temperature $\left(107^{\circ} \mathrm{C}\right)$, thus characterizing a new type of polymeric material, with a predominantly crystalline area.

The results of DSC on the polyethylene/starch blends submitted to biodegradation test with the mixed culture of the chrysosporium and 
wortmannii for 30 days presented a small variation in the melting temperature, as well as a decrease in the fusion temperature, which indicated an alteration of the degree of crystallinity of the polyethylene/starch mixture (Table 2), deriving from the degradation of the blends by the fungi when compared to the blends without the presence of the fungi (standard).

Table 3 shows the results of the mechanical tests of the polyethylene/starch blends before and previously submitted to biodegradation test. The blends that were inoculated with the fungi $\left(A_{1}\right)$, presented a $32 \%$ decrease in the tensile strength, whereas the elongation at break presented a $5 \%$ increase when compared to the blends that were not inoculated with the microorganisms (B). There was no significant difference in the mechanical properties of the blends without inoculation $\left(\mathrm{A}_{0}\right)$ of the fungi with the standard (B).
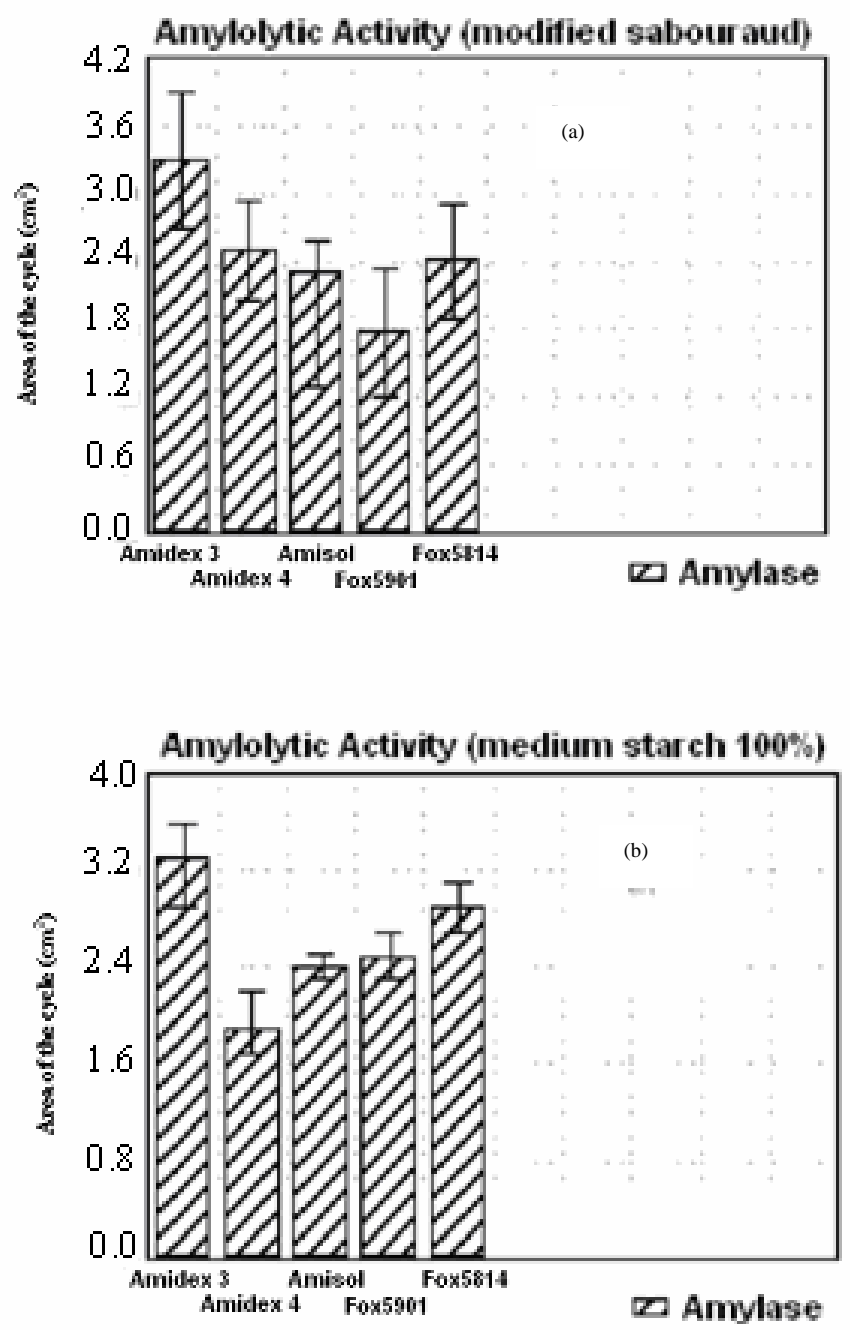

Figure 3 - Amilolytic activity of the Talaromyces wortmannii in the medium modified Sabouraud (10g starch/10g glicose). 


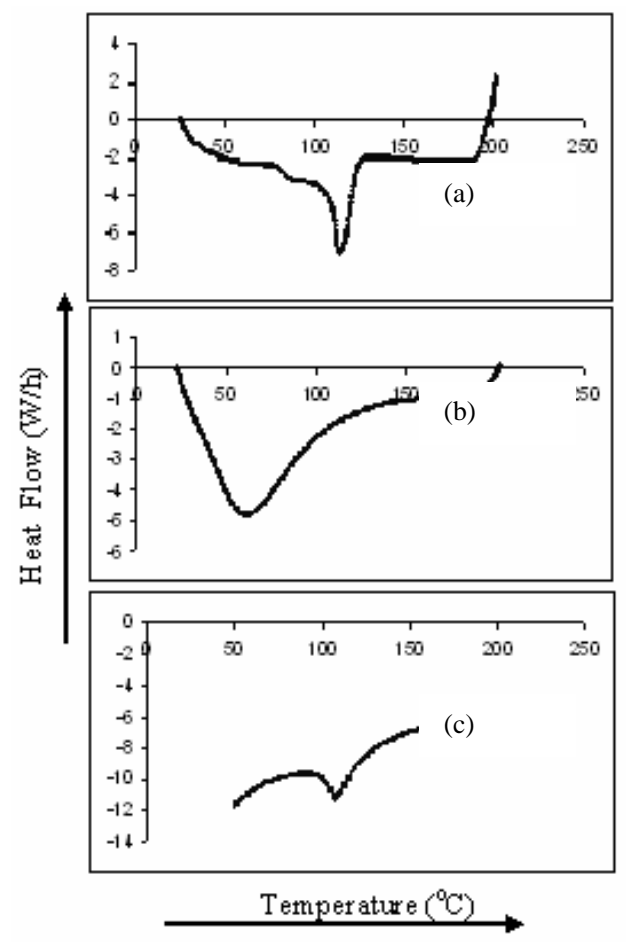

Figure 4 - Thermal analysis of the a) LDPE, b) starch and c) LDPE/starch blend.

Table 2- Results of the thermal analysis of LDPE, Starch, and polyethylene/Starch blends before and previously submitted to biodegradation test.

\begin{tabular}{cccc}
\hline Sample & Incubation period (days) & $\mathbf{T}_{\mathbf{m}}\left({ }^{\mathbf{0}} \mathbf{C}\right)$ & $\Delta \mathbf{H}_{\mathbf{m}}(\mathbf{W} / \mathbf{h})$ \\
\hline Ao & 0 & 107,5 & 11,2 \\
B & 30 & 107,4 & 18,9 \\
$\mathrm{~A}_{1}$ & 30 & 109,8 & 9,17
\end{tabular}

$\mathrm{A}_{0}=$ polyethylene/ starch blend without inoculation.

$\mathrm{A}_{1}=$ polyethylene/ starch blend after inoculation of the fungi, period 30 days.

$\mathrm{B}=$ standard (polyethylene/ starch blend in the same conditions of A1 without the presence of the fungi).

Table 3- Results of the mechanical properties of the polyethylene/starch blends before and after the biodegradation.

\section{Sample}

$\mathrm{A}_{0}$

$\mathrm{A}_{0}$

B

$\mathrm{A}_{1}$
Incubation period (days)

\section{$\sigma($ MPa)}

$5.69 \pm 0,54$

$4.70 \pm 0.56$

$31.06 \pm 0,56$

$3.22+0.33$

$\mathrm{A}_{0}=$ polyethylene/ starch blend without inoculation.

$\mathrm{A}_{1}=$ polyethylene/ starch blend after inoculation of the fungi, period 30 days.

$\mathrm{B}=$ standard (polyethylene/ starch blend in the same conditions of A1 without the presence of the fungi).

$\% \mathrm{El}=$ percentage elongation at break .

$\sigma=$ Tensile strength 
It could be believed that with the increased time of exposure of the blends to the fungi, the modifications of the mechanical and thermal properties should be more accentuated since the microorganisms would continue to act on the biodegradation process. This hypothesis was based on the Sturm method results that followed the production of $\mathrm{CO}_{2}$ (Rosa et al., 2001; Lima, 2005).

\section{CONCLUSION}

The cellular growth of the isolated and mixed cultures of the chrysosporium and wortmannii, in the different types of starch in the culture medium containing 25 and $100 \%$ starch was studied. The regular starch Amidex 3 and the modified starch Fox5901 presented better performances. wortmannii proved to be a good producer of the amylase enzyme in different types of starch and in the culture medium containing 25 and $100 \%$ starch. The regular starch, Amidex 3 and the modified starch Fox5901 presented better results. In spite of the short time that the blends were exposed to the fungi, it was concluded that the microorganisms promoted physical and chemical changes in the structure of the blend, modifying its thermal and mechanical properties. The alteration of the degree of crystallinity and the decrease in the tensile strength as well as the increase in the percentage of elongation at break, indicated the modification caused by the biodegradation process.

\section{ACKNOWLEDGEMENTS}

We would like to thank Dr. Laura Hecker and Dr. Suédina M. de Lima Silva (DEMA - Universidade Federal de Campina Grande - Brazil) for allowing the use of the laboratory and equipment for the preparations of the blends. Also the financial support from CAPES, FACEPE and CNPq are gratefully acknowledged.

\section{RESUMO}

Nesse trabalho foi realizado um estudo sobre diferentes tipos de amido quanto ao crescimento, e a atividade amilolítica de culturas mistas e isoladas dos fungos Phanerochaete chrysosporium e Talaromyces wortmannii. Avaliaram-se também as propriedades térmicas e mecânicas das blendas de polietileno/amido anfótero (na proporção 80/20 $(\mathrm{m} / \mathrm{m})$ ) antes e apos a inoculação das culturas mistas desses fungos. $\mathrm{O}$ amido regular Amidex $3 \mathrm{e}$ o amido modificado Fox5901 foram os que se destacaram quanto ao crescimento celular e produção da enzima amilase. Apesar do pouco tempo de exposição dos filmes com os fungos, pode-se concluir que os microrganismos promovem mudanças físicas e químicas na estrutura da blenda, modificando suas propriedades térmicas e mecânicas. A alteração do grau de cristalinidade e das propriedades mecânicas das blendas podem ser indícios da modificação provocada pelo processo de biodegradação.

\section{REFERENCES}

Aitken, M.D; Irvine, R.I. (1989), Stability testing of ligninase and Mn-peroxidase from Phanerochaete chrysosporium. Biotechnology and Bioengineering., 34, 1251-1260.

Baldev Raj, V.; Annadurai, R.; Somashekar, M. R. and. Siddaramaiah, S. (2001), Structure-property relation in low-density polyethylene-starch immiscible blends. European Polymer Journal., 37, 943-948.

Bonhomme, S; Cuer, A.; Delort, A-M; Lemaire, J.; Sancelme, M.; Scott, G. (2003), Environmental biodegradation of polyethylene. Polymer Degradation and Stability., 81, 441-452.

Cha, Y. and Pitt, C.G. (1989), The biodegradability of polyester blends. Biomaterials. 11, 108-112.

Chandra, R. and Rustgi, R. (1997), Biodegradation of maleated linear low-density polyethylene and starch blends. Polymer Degradation and Stability., 56, 185202.

Dey S., Maiti T. K., Saha N., Banerjee R. and Bhattacharyya B. C. (1991), Extracellular protease and amylase activities in ligninase-producing liquid culture of Phanerochaete chrysosporium. Process Biochemistry., 26, 325-329.

Domsch, K.H., Gams, W. (1980), Compedium of soil fungi. Academic press INC. NY, USA, v. 1, p. 758759.

Dupret, I.; David, C.; Daro, A. (1999), Biodegradation of polyester-amides using a pure strain of microorganisms or papain. II. Polymer Degradation and Stability. , 67, 505-513. 
Eriksson, K.E; Blanchette, R.A; Ander (1990), P. Microbial and enzymatic degradation of wood and wood components. Springer-verlag, New York, pp.13-16.

Gupta, R.; Gigras P.; Mohapatra, H.; Goswami, V. K. and Chauhan, B. (2003), Microbial $\boldsymbol{\alpha}$-amylases: a biotechnological perspective. Process Biochemistry., 38, 1599-1616.

Kim M. (2003), Evaluation of degradability of hydroxypropylated potato starch/polyethylene blend films. Carbohydrate Polymers., 54, 173-181.

Lee, B. T; Pometo, A.L; Fratzke, A; Bailey JR, T.B. (1991), Biodegradattion of degradable plastic polyethylene by Phanerochate and Streptomyces. Applied Environmental Microbiology., 57, 678-685.

Lima, S. M. (2005), Estudo da Capacidade Biodegradadora de culturas de fungos em blendas poliméricas biodegradáveis. Tese de Mestrado, Universidade Federal de Pernambuco, Recife, Pernambuco, Brasil.

Lima, M.A.G.A. (1999), Obtenção e caracterização de xantanas produzidas por diferentes linhagens de Xanthomonas campestris pv. campestris. Doutorado em Engenharia Química Tese, Escola de Química da Universidade Federal do Rio de Janeiro, Brasil.

Matzinos, P. Tserki, V. Gianikouris, C. Pavlidou, E. and Panayiotou, C. (2002), Processing and characterization of LDPE/starch/PCL blends. European Polymer Journal., 38, 1713-172.

Miller, J. C.; Miller, J. L. (1984), Statistics for analytical chemistry. Ellis Horwood, Chichester, England, pp. 52-79.

Nakamura E. M. L.; Cordi G.S.G; Almeida, N. Duran, L.H.I. (2005), Study and development of LDPE/starch partially biodegradable compounds. Journal of Materials Processing Technology., 162, 236-241.

Orhan, Y; Buyukgungor, H. (2000). Enhancement of biodegradability of disposable polyethylene in controlled biological soil. Samsun: Elsevier Science Publishers Ltd. Turkey.

Pedroso, A.G. and Rosa, D.S. (2005), Mechanical, thermal and morphological characterization of recycled LDPE/corn starch blends. Carbohydrate Polymers., 59, 1-9.

Ratto, J. A.; Stenhouse, P. J.; Auerbach, M.; Mitchell, J.; Farrell, R. (1999), Processing, performance and biodegradability of a thermoplastic aliphatic polyester/starch system. Polymer., 40, 6777-6788.
Rodrigues, H. Garcia. (1993), Azúcar e Derivados de La Caña, 3, B. Diversification - 93. Paper presente at Seminário Internacional de Havana.

Rodriguez-Gonzalez, F. J.; Ramsay, B. A. and Favis, B. D. (2003), High performance LDPE/thermoplastic starch blends: a sustainable alternative to pure polyethylene. Polymer., 44, 1517-1526.

Roldán-Carrillo, T., Rodríguez-Vázquez, R., Díazcervantes, D., Vázquez-Torres, H., Manzur-Guzmán, A. e Torres-Domínguez, A. (2003), Starch-based plastic polymer degradation by the white rot fungus Phanerochaete chrysosporium grown on sugarcane bagasse pith: enzyme production. Bioresource Technology., 86, 1-5.

Rosa, D.S., Franco, B.L.M., Calil, M.R. (2001), Biodegradabilidade e propriedades mecânicas de novas misturas poliméricas, Polímeros: Ciência $e$ Tecnologia., 11, 82-88.

Shah, P. B., Bandopadhyay, S., Bellare, J.R. (1995), Environmentally degradable starch filled low density polyethylene, Polymer Degradation and Stability., 47, 165-173.

STATISTICA for Windows. StatSoft. (1998), Inc. 2300 East 14th Street, Tulsa, OK, 74104, USA.

Thakore, I.M.; Desai, S.; Sarawade, B.D.; Devi, S. (2001), Studies on biodegradability, morphology and thermo-mechanical properties of LDPE/modified starch blends. European Polymer Journal., 37, 151160.

Zuchowska, D.; Steller, R.; Meissner, W. (1998), Structure and properties of degradable polyolefinstarch blends. Polymer Degradation and Stability., 60, 471-480.
Received: November 30, 2004; Revised: October 03, 2005; Accepted: March 19, 2007. 